\title{
Analysis of Behaviour of Prefabricated Staircases with One-sided Suspended Stairs
}

\section{Analiza ponašanja montažnih konzolnih stubišta}

\author{
Professional paper • Stručni rad \\ Received-prispjelo: 9. 7. 2013. \\ Accepted-prihvaćeno: 20. 5. 2015. \\ UDK: $630 * 831.9 ; 630 * 812.7$ \\ doi:10.5552/drind.2015.1338
}

\begin{abstract}
The article introduces a potential use of a combination of the method of numerical modelling and experimental tests for the treatment of the structure of a wooden prefabricated staircase with one-sided suspended stairs. Numerical modelling was used to find critical details, which were experimentally tested on partial models in the scale 1:1. The results of the numerical modelling in combination with experimental testing were used for designing a prototype of a wooden prefabricated staircase with one-sided suspended stairs. The designed prototype of a staircase in two versions was experimentally tested in the scale 1:1 in compliance with Czech design standards ČSN 73 0035, ČSN 732030 and ETAG008 - Guideline for European technical approval of prefabricated stair kits in edition January 2002 in terms of ultimate and serviceability state design.
\end{abstract}

Key words: analysis of behavior, prefabricated staircase, numerical modelling, experimental testing

SAŽETAK • Članak obrađuje potencijalnu primjenu kombinacije metode matematičkog modeliranja i eksperimentalnih ispitivanja za obradu konstrukcije drvenih montažnih konzolnih stubišta. Numeričko modeliranje primijenjeno je za pronalazak kritičnih detalja koji su eksperimentalno testirani na parcijalnim modelima u mjerilu 1:1. Rezultati numeričkog modeliranja, u kombinaciji s eksperimentalnim ispitivanjem, primijenjeni su za izradu prototipa drvenih montažnih konzolnih stubišta. Dizajnirani prototip stubišta u dvije verzije eksperimentalno je ispitan u mjerilu 1:1 radi utvrđivanja ponašanja stubišta u upotrebi, u skladu s češkim standardima ČSN 73 0035, ČSN 732030 i ETAG008 - Smjernica za europske tehničko odobrenje setova montažnog stubišta, iz siječnja 2002. godine.

Ključne riječi: analiza ponašanja, montažno stubište, numeričko modeliranje, eksperimentalna ispitivanja

\section{INTRODUCTION \\ 1. UVOD}

When connecting two height levels during building of residential houses, the current trend is to use light and airy staircases with attractive and modern de- sign. Staircases are often perceived by architects and end users, i.e. investors, as architecture elements that help to create a visual style and well-being of a modern home (Jiricna, 2001). The right choice of a staircase contributes to elegance, originality, and a unique style of a building (Karre, 2005).

\footnotetext{
${ }^{1}$ Authors are associate professors at Institute of Building Structures, Faculty of Civil Engineering, Brno University of Technology, Czech Republic. ${ }^{2}$ Authors are assistant professors and Department of Wood Processing, Faculty of Forestry and Wood Technology, Mendel University in Brno, Czech Republic.

${ }^{1}$ Autori su izvanredni profesori Zavoda za građevinske konstrukcije, Građevinski fakultet, Tehnološko sveučilište u Brnu, Republika Češka.

${ }^{2}$ Autori su docenti Odsjeka za preradu drva, Fakultet šumarstva i drvne tehnologije, Mendelovo sveučilište u Brnu, Češka Republika.
} 
The choice of the construction system of staircases is also related to the choice of material (Habermann, 2002). Nowadays, various material alternatives are combined; for example it is possible to see frequent use of wood with other material, e.g. stainless steel, glass, stone and fibreglass. In addition, there are many examples of use of just a single material, most commonly wood.

Some examples of staircases that meet the mentioned qualities, i.e. elegance, originality, airiness, and unique and modern style, include staircase bolts with inserted treads, or with central staircase bolt, or spiral staircases. The mentioned types of staircases are produced by a wide range of companies in the Czech Republic and in EU countries. The extensive list of companies includes e.g. SWN Moravia, s.r.o., TREPP-ART s.r.o., Bucher $\mathrm{GmbH}$, Kenngott Treppen $\mathrm{GmbH}$, and others.

Within a project of MPO ČR IMPULS, registration number FI-IM2/053 titled "Research and Development of a New Generation of Staircases to Residential and Civil Buildings", the issue was the construction of wooden prefabricated staircases with one-sided suspended stairs. In accordance with the objectives of the project, a new generation of prefabricated staircases with one-sided suspended stairs was developed in the form of a prototype of a staircase in two versions. The modernized generation of prefabricated staircases improved the universality and variability of the construction system, brought lower costs on production thanks to material saving and simpler production and assembly.

The development of a new generation of staircases and the design of its prototype took advantage of a method of numerical modelling in combination with experimental testing. The combination was also used by other authors (Pousette, 2003; Pousette, 2006; Labans and Kalninšs, 2012; Franke and Quenneville, 2011; Fleischmann et al., 2005). The method of numerical modelling is used for the issues of construction mechanics, or dynamics, i.e. static analysis, dynamic analysis of analyzed structure or a detail with the use of a finite element method (Tankut et al., 2014). Using the outputs of numerical modelling, an evaluation of an analysed structure can be performed according to standard regulations, and critical construction points identified. These points can be modified and re-analysed thanks to the method of numerical modelling. Subsequently, the first phase of verifying details behaviour with the use of experimental tests of partial testing models will be performed. After verifying the correct design of details, an experimental analysis of the construction should be performed in the second phase, in order to find whether the designed structure complies with the existing standard criteria.

\section{MATERIALS AND METHODS 2. MATERIJALI I METODE}

\subsection{Structure of prefabricated staircases with one-sided suspended stairs}

2.1. Konstrukcija montažnoga konzolnog stubišta

A prefabricated staircase with one-sided suspended stairs (Fig. 1) consists of stairs without risers, which leads to a lighter construction.

The stairs at the side of the wall are usually anchored in the bearing wall with the use of 2 steel bars and partly anchored in the staircase bolt. In order to eliminate footfall sound spreading into bearing walls, the bars are put in rubber cases in the wall. A part from this type of mounting, the mounting used in the design of the staircase prototype can be used as well. At the outer side, the stairs are suspended with the system of bars anchored in a massive handrail. The height position of stairs is delineated with the use of distance elements, which are placed in between stairs on a stair edge. The details of the wooden prefabricated staircase are shown in Fig. 2.

The staircase is predominantly made of glued wooden profiles of European beech (Fagus sylvatica), European white oak (Quercus petrea), Scotch pine (Pinus sylvestris) and spruce (Picea abies), which improve
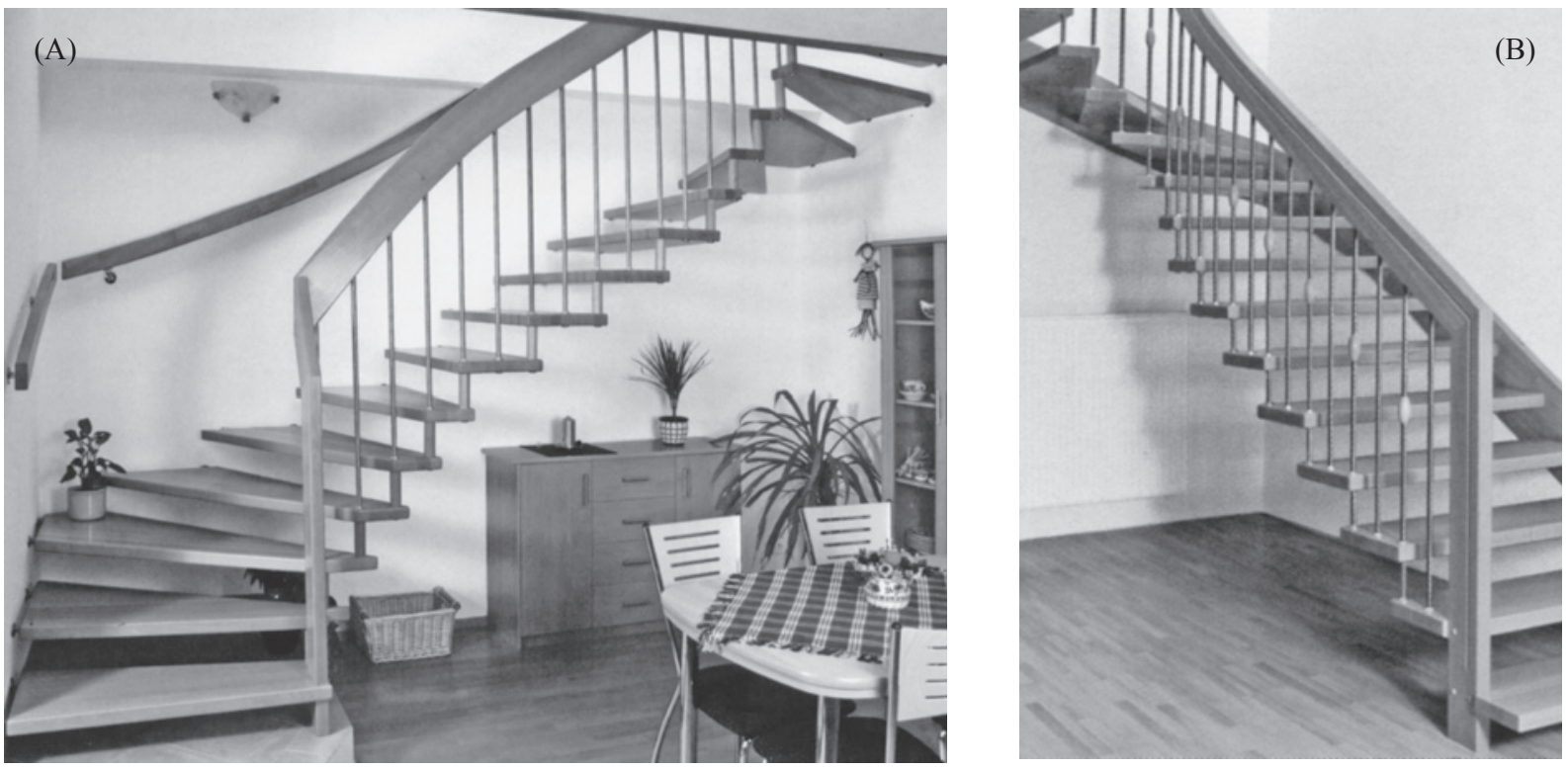

Figure 1 Prefabricated staircase with one-sided suspended stairs (Jema Svitavy a.s., 2006)

Slika 1. Montažno konzolno stubište (Jema Svitavy a.s., 2006.) 

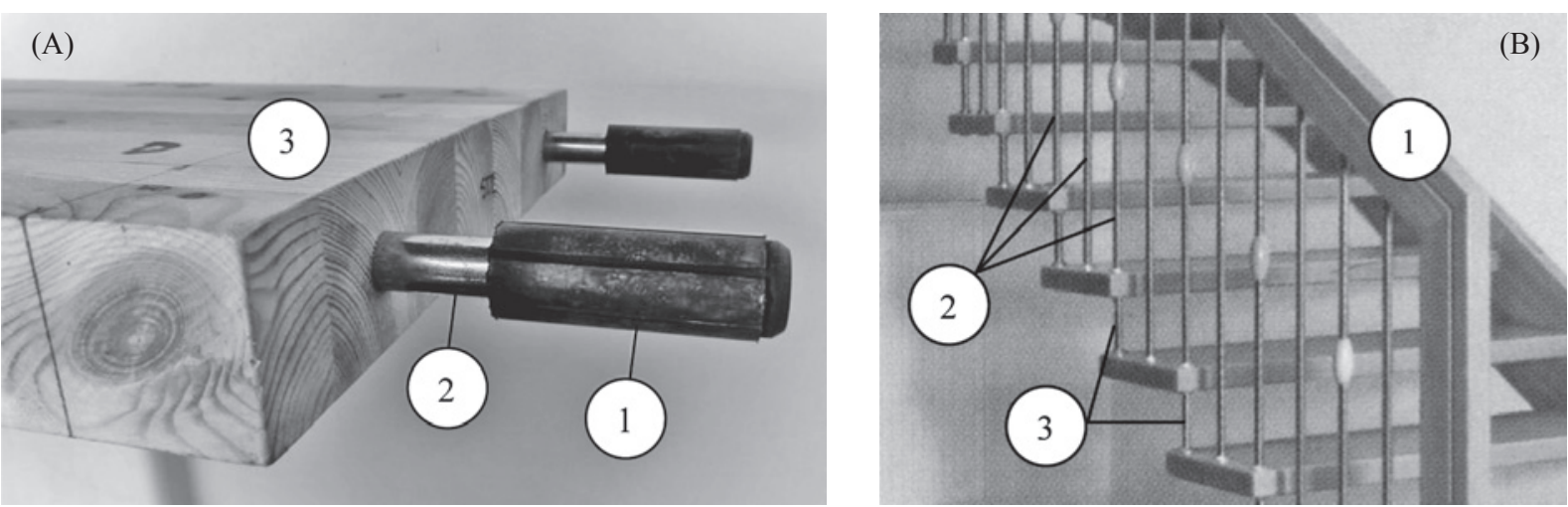

Figure 2 Details of the wooden prefabricated staircase: (A) Detail at the side of the wall (1 - rubber cases, 2 - steel bars, 3 - stair); (B) Detail at the side of the massive handrail (1 - massive handrail, 2 - system of bars, 3 - distance elements) (Jema Svitavy a.s., 2006)

Slika 2. Detalji drvenoga montažnog stubišta: (A) detalj sa strane zida (1 - gumeni dijelovi, 2 - čelične šipke, 3 - gazište stube); (B) detalj masivnog rukohvata (1 - masivni rukohvat, 2 - sustav šipaka, 3 - elementi koji određuju udaljenost stuba) (B: Jema Svitavy a.s., 2006.)

the shape durability and eliminate the effect of torsion of profiles, in the versions of connected profiles and nonconnected profiles. The thickness of profiles ranges between 40 and $65 \mathrm{~mm}$. The non-wooden parts are designed from stainless steel, or surface treated steel.

\subsection{Static analysis of behaviour of prefabricated staircases with one-sided suspended stairs}

2.2. Statička analiza ponašanja montažnoga konzolnog stubišta

In order to study the behaviour of prefabricated staircases with one-sided suspended stairs, a straight staircase was selected, which represents the most unfavourable arrangement in terms of statics.

Regarding the use of prefabricated staircases for building residential houses, a staircase made form Scotch pine (Pinus sylvestris) with the construction height of $3.0 \mathrm{~m}$, aligned span of $4.862 \mathrm{~m}$ and ground distance of $3.98 \mathrm{~m}$ was considered (Fig. 3a). Dimensions of stairs without risers of $900 \mathrm{~mm}$ comply with the requirements of a Czech design standard ČSN 734130 for residential houses. The width of stairs at the walking line of $314 \mathrm{~mm}$ was designed with the stairs overlap of $10 \mathrm{~mm}$. The thickness of stairs of $50 \mathrm{~mm}$ was designed taking into account the existing way of production. The dimensions of the handrail and newels were designed to be made of glued wooden profile $50 \times 140 \mathrm{~mm}$.

At the outer side, the stairs were suspended with the use of a system of steel bars (24 pieces) of profile of $\varnothing 12 / 2 \mathrm{~mm}$ to the bearing massive handrail, which is taken along the outer side of the whole staircase. Each stair was suspended on three bars (Fig. 1) and (Fig. 2) and was connected with the previous and the following stair with the use of wood distance elements (Fig. 1a). At the wall side, the stairs were placed with the use of 2 steel bars $\varnothing 16 \mathrm{~mm}$ that were embedded in the bearing wall through rubber cases (Fig. 2a).

\subsection{FE modelling}

\subsection{FE modeliranje}

A static analysis by FEM software systems was performed for loading in compliance with Czech design standard ČSN EN 1991-1-1 (73 0035) Eurocode
1: Action on Structures - Part 1-1: General actions Densities, self-weight, imposed loads for buildings. Within the analyses dead load was considered, i.e. selfweight and live load, which was considered as uniform load, concentrated load of stairs, and concentrated load acting in vertical and horizontal direction of the handrail. The load was considered in characteristic and design values, which were set in compliance with article 6.10 of Czech design standard ČSN EN 1990 (73 0002) Eurocode: Basis of structural design.

The initial static analysis of behaviour of the selected prefabricated staircase with one-sided suspended stairs and the performance of a standard evaluation of this structure, according to Czech design standard ČSN EN 1995-1-1 (73 1701) Design of timber structures, Part 1-1: General - Common rules and rules for buildings, was performed with the use of a 3D beam analysis model and software IDA NEXIS 32 (2002).

In order to perform a detailed analysis of behaviour of the prefabricated staircase with one-sided suspended stairs, a 3D analysis model and partial analysis models of details (connection of the top and bottom newel with the handrail, a detail of the mounting of a stair on steel bars, detail of the connection of stairs through distance elements) were developed in the software ANSYS (2012a).

A 3D analysis model, where a fixed connection of all construction parts was assumed, was developed with the use of finite elements type of SOLID45, SOLID92, SOLID95 and SURF154 (ANSYS, 2012b). 3D models (Fig. 3) were developed for stairs, rubber cases, connecting screws, screw washers, bars, distance elements, handrail, and top and bottom newels.

Partial analysis models of massive handrail and bottom newel connections (Fig. 3b) using submodelling methods (ANSYS, 2012c) were developed with the use of finite elements of the type of SOLID92 (ANSYS, 2012b). The real glued connection between the handrail and newels was considered for these models. The connections were modelled with contact elements TARGE170 and CONTA174 (ANSYS, 2012b). In this case, the contact elements allowed the contact to 
(A)

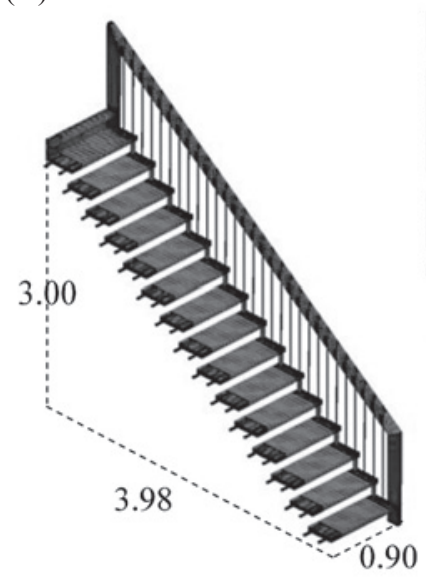

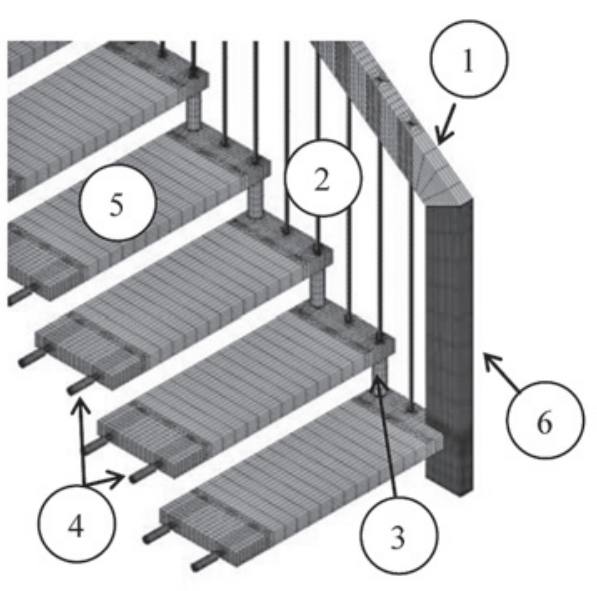

(B)

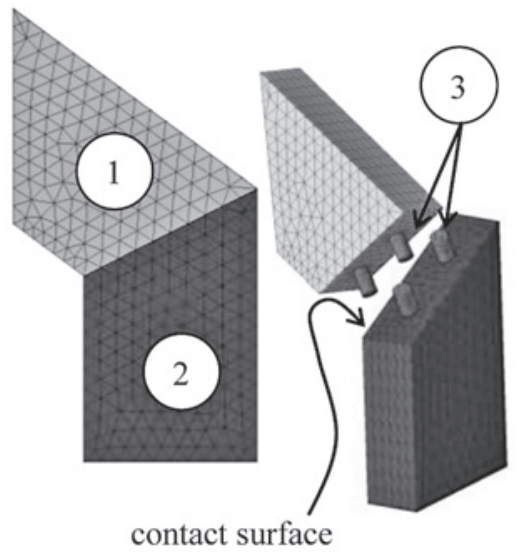

Figure 3 3D analysis model (A): 3D analysis model and its detail; dimension in m; (1 - massive handrail, 2 - system of bars, 3 - distance elements, 4 - rubber cases, 5 - stair, 6 - bottom newel) (B): Partial analysis models of massive handrail and bottom newel connections (1 - massive handrail, 2 - bottom newel, 3 - connection pin) with contact surface between 1, 2 and 3

Slika 3. 3D model analize (A): 3D model analize s detaljima (dimenzije u m) (1 - masivni rukohvat, 2 - sustav šipki, 3 - elementi kojima se određuje udaljenost stuba, 4 - gumeni dijelovi, 5 - stuba, 6 - donja ograda); (B) modeli djelomične analize spoja masivnog rukohvata i donje ograde (1 - masivni rukohvat, 2 - donja ograda, 3 - spoj između rukohvata i donje ograde) s kontaktnom površinom između 1,2 i 3

open up, or a connection in the case of exceeded value of shear and normal stress, which equalled the value of glue strength of $10 \mathrm{MPa}$ (Pěnčík and Lavický, 2006).

In the $3 \mathrm{D}$ analysis model and partial analysis models of details, the behaviour of wooden parts from Scotch pine (Pinus sylvestris) was described in the software ANSYS with the use of an orthotropic material model (Table 1). Material properties were taken from (Požgaj et al., 1997; Matovič, 1993; 2004).

With the use of orthotropic material model, general anisotropic material properties of wood caused by different properties in different anatomic directions of wood were simplified, i.e. longitudinal direction $L$, tangent direction $T$ and radial direction $R$ (Požgaj et al., 1997; Kretschmann, 2010; Mascia and Lahr, 2006; Bucur, 2006). The possibility of using an orthotropic material model is related to the method of producing laminated wooden profiles. When producing the laminated wooden profiles, it is possible to clearly define just the longitudinal direction $L$, which is identical to the direction of wood grains. The other anatomic directions of wood cannot be clearly determined due to the different orientation. This is the reason why the similar properties were considered for tangent $T$ and radial $R$ directions. Regarding the dimensions of the wooden elements, the material characteristics determined for the cylindrical system $L T R$ were used for the Cartesian system XYZ (Danielsson and Gustafsson, 2013), where the material is considered to have similar properties in the direction $Y$ and $Z$.

The behaviour of connecting elements and rubber cases was ideally modelled with the use of an iso- tropic material model. The steel elements were included in the analysis through material characteristics for steel S235. The isotropic material model of rubber cases was described by modulus of elasticity $10 \mathrm{MPa}$ (2012), density $50 \mathrm{~kg} / \mathrm{m}^{3}$ and Poisson's ratio 0.475 .

Boundary conditions concerning the $3 \mathrm{D}$ analysis model originated from the real support. The simple support was considered at the contact of the bottom newel to the bearing floor structure. The fixation of the staircase to the bearing ceiling structure was considered with the use of a board under the last stair anchored in the ceiling with three screws. Regarding the rubber cases, boundary conditions were defined to their cylindrical surface in the cylindrical coordinate system while preventing the case face movement out of the wall.

The analyses made with the use of the 3D analysis model and detailed analysis models were materially linear and geometrically nonlinear. The 3D analysis model was loaded in compliance with a Czech design standard ČSN EN 1991-1-1. Due to the use of the method of sub-modelling, the partial analysis models were only loaded by deformation load, which was determined with the use of an analysis of the $3 \mathrm{D}$ analysis model, i.e. the load of the partial analysis models was taken over from the output of the 3D analysis model.

After the solution of the 3D analysis model, as well as detailed analysis models, the evaluation of results was performed. The evaluation determined the field of displacement $\left(U_{Y}, U_{S U M}\right)$ and field of stress $\left(S_{X}\right.$, $S_{Y}, S_{Z}, S_{1}, S_{3}$ ). The vertical displacement $U_{Y}$ and normal stress in the direction of grains for uniformly loaded

Table 1 Material properties of Scotch pine (Pinus sylvestris) in notation of ANSYS (ANSYS, 2012a)

Tablica 1. Obilježja borovine (Pinus sylvestris) zapisana u programu ANSYS

\begin{tabular}{|c|c|c|c|c|c|}
\hline$E X, \mathrm{MPa}$ & 14300 & $G X Y, \mathrm{MPa}$ & 800 & NUXY & 0.04 \\
\hline$E Y, \mathrm{MPa}$ & 545 & $G Y Z, \mathrm{MPa}$ & 500 & NUYZ & 0.38 \\
\hline$E Z, \mathrm{MPa}$ & 700 & $G X Z, \mathrm{MPa}$ & 1230 & NUXZ & 0.03 \\
\hline$D E N S, \mathrm{~kg} / \mathrm{m}^{3}$ & 505 & & & & \\
\hline
\end{tabular}



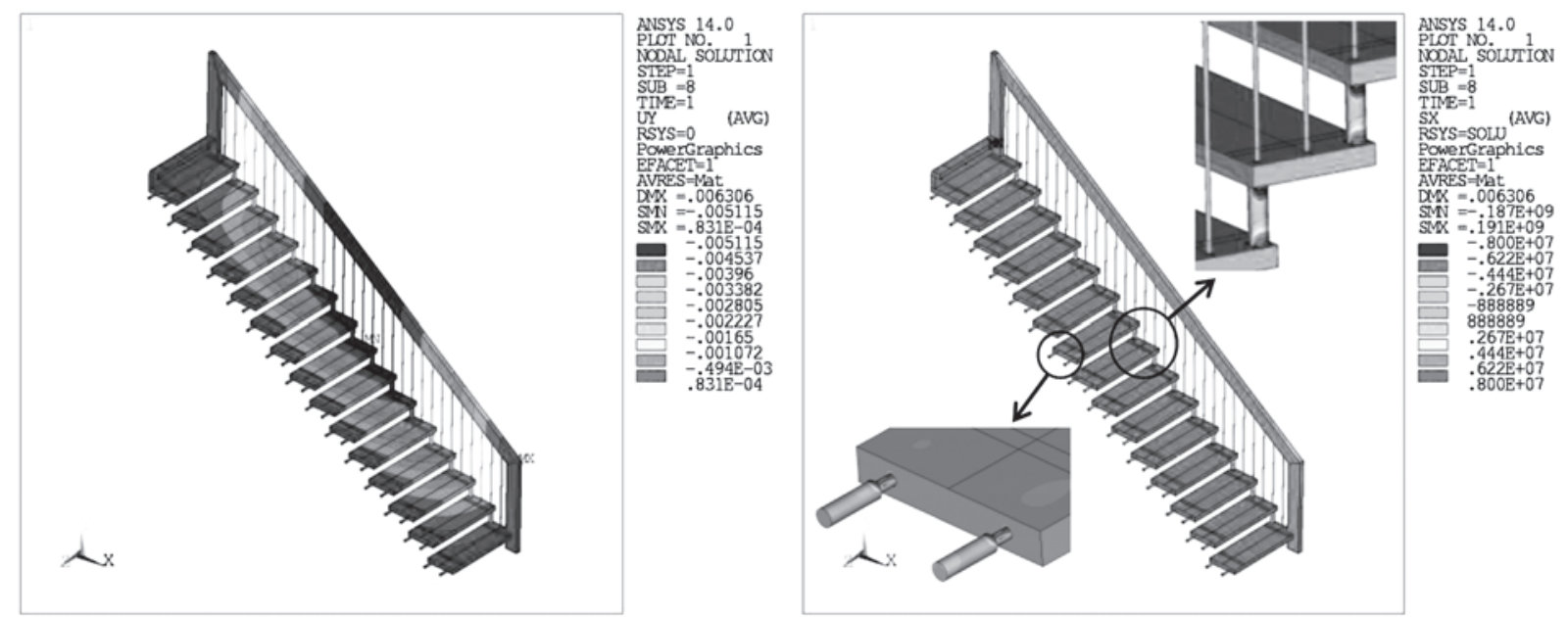

Figure 4 3D analysis model - results for uniformly loaded staircase in intensity of uniform serviceability load $V=3.0 \mathrm{kN} / \mathrm{m}^{2}$ and self-weight (A): Vertical displacement $U_{Y}(\mathrm{~m})(\mathrm{B})$ : Normal stress in the direction of grains $(\mathrm{Pa})$ in the interval $\langle-8 ;+8\rangle$ $\mathrm{MPa}$; examples of "critical" places

Slika 4. 3D model analize - rezultati za ravnomjerno opterećeno stubište pri opterećenju $V=3,0 \mathrm{kN} / \mathrm{m}^{2}$ i uz vlastitu težinu: (A) vertikalni pomak $U_{Y}(\mathrm{~m})$; (B) normalno naprezanje u smjeru vlakanaca $(\mathrm{Pa}) \mathrm{u}$ intervalu $\langle-8 ;+8\rangle \mathrm{MPa}$; primjeri kritičnih mjesta

staircase in intensity of uniform serviceability load $V=3.0 \mathrm{kN} / \mathrm{m}^{2}$ (ČSN EN 1995-1-1, 2004) and selfweight is shown in Fig. 4. The average values of normal stress and principal stress in individual wooden construction parts of the staircase were in the range of the interval of the wood strength. The stress was distributed uniformly in the majority of construction parts of the staircase. Using interactive failure criteria Hoffman's criterion (Hoffman, 1967; Berthelot, 1998; Galicky and Czech, 2013) and Tsai-Wu criterion (Tsai and Wu, 1971; Danielsson and Gustafsson, 2013; Galicky and Czech, 2013) "critical" places of the staircase structure were identified (places of the contact of distance elements with stairs, at places of laying stairs on steel bars, at places of the suspension of stairs with the use of steel bars, and at places of the handrail contact with the top, or bottom, newel).

The "critical" places of the staircase structure were subsequently changed in order to reduce the con- centration of stress at places of these details. The designed changes were numerically reanalysed. After their numerical verification, they were integrated in the prototype design of the prefabricated staircase with one-sided suspended stairs (Fig. 5).

\section{RESULTS AND DISCUSSION} 3. REZULTATI I RASPRAVA

Based on the results of numerical analyses from the 3D model, a prototype of a wooden straight prefabricated staircase was made from Scotch pine (Pinus sylvestris) with one-sided suspended stairs in two versions. The prototype design applied the proposed changes based on the numerical analyses. The changes included the reduction of the number of bars from 24 pieces for the whole staircase (Fig. 5) to 4 pcs, the reduction of the thickness of steps from $50 \mathrm{~mm}$ to $40 \mathrm{~mm}$, the change of the anchoring of stairs in the bearing (a)

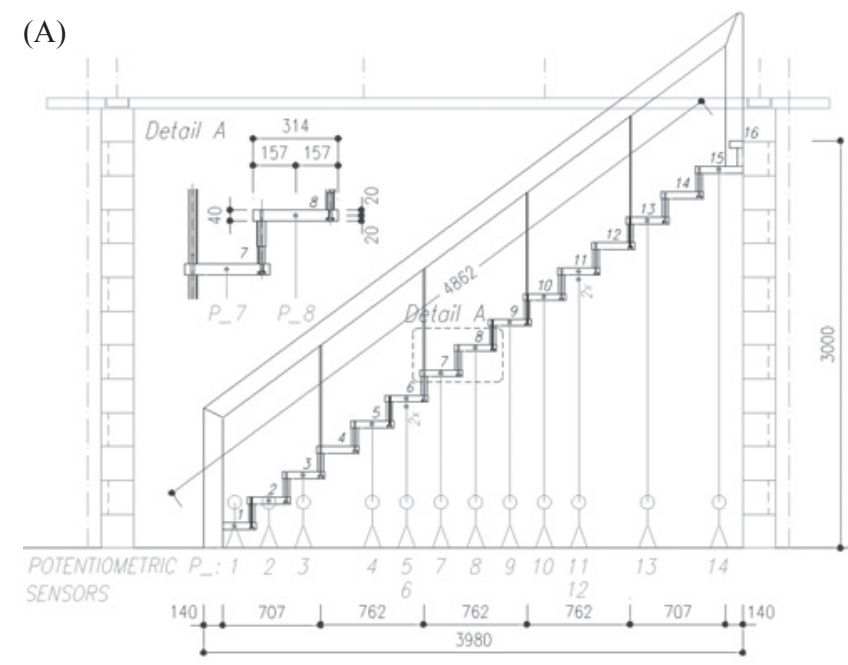

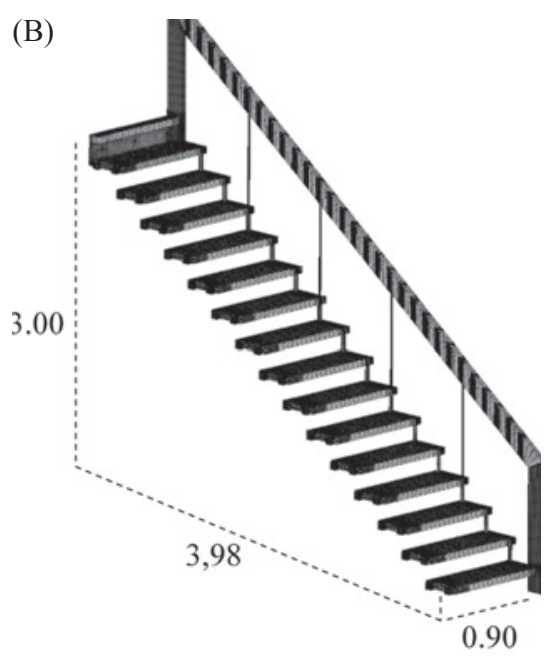

Figure 5 Prototype of a wooden straight prefabricated staircase: (A) Dimensions and measuring points with potentiometric sensors of the type MS04; (B) 3D analysis model

Slika 5. Prototip drvenoga ravnog montažnog stubišta: (A) dimenzije i mjerne točke s potenciometrijskim senzorima tipa MS04; (B) 3D model analize 

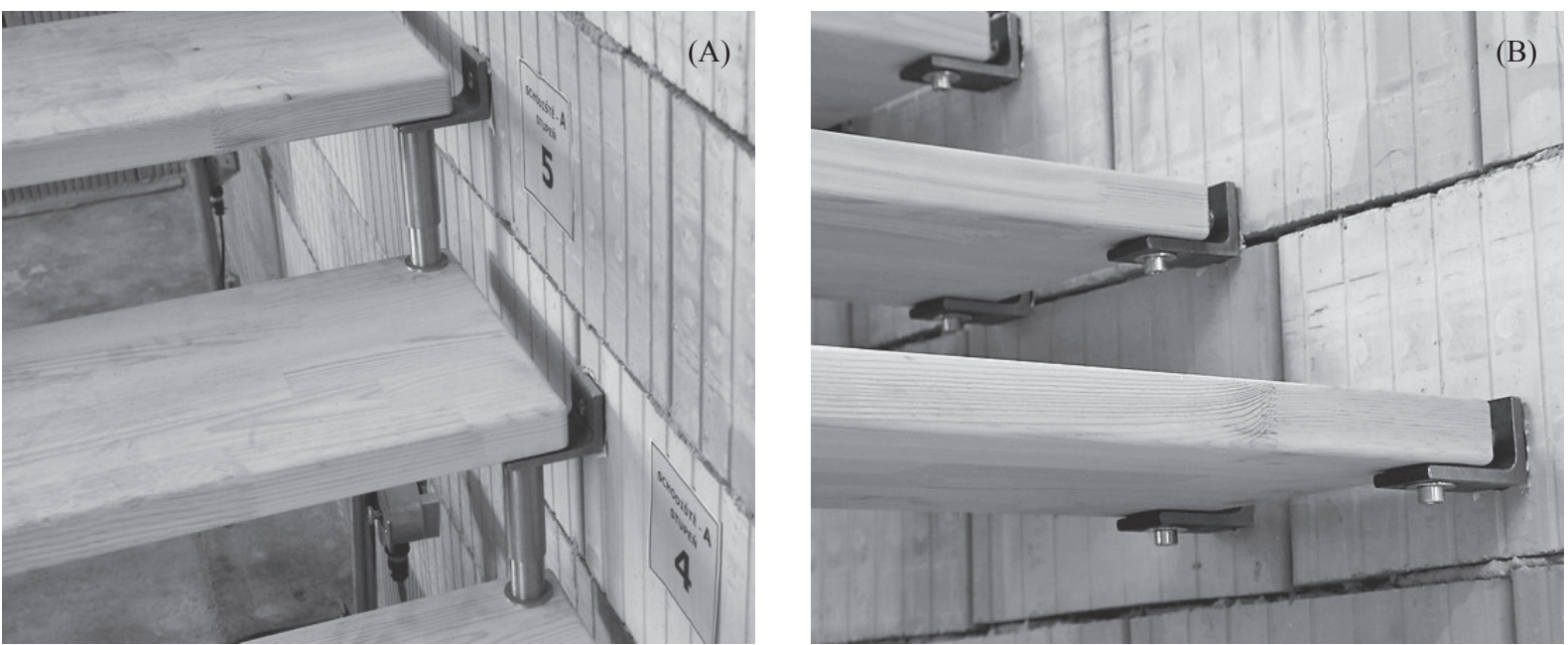

Figure 6 Different ways of fixing the stairs into the bearing wall: (A) Version A (the stairs supported by a steel profile and by a distance element); (B) Version B (the stairs supported by two steel profiles)

Slika 6. Različiti načini učvršćenja stubišta u nosivi zid: (A) verzija A (nosivi su elementi čelični profil i element koji određuje udaljenost između stuba); (B) verzija B (nosivi su elementi stuba dva čelična profila)

wall, the modification of solutions of distance elements through improved universality by height rectification, and the change of the contact of the top and bottom newel with the handrail was designed.

The two versions of the prototype of a wood straight prefabricated staircase differed in the way the stairs were fixed into the bearing wall. In the first version marked A, the stairs were supported at the entry edge by a steel profile $\mathrm{L} 80 \times 60 \times 8 \mathrm{~mm}$ and at the exit edge by a distance element made of stainless steel (Fig. 6a) without being fixed to the bearing wall. In the other version marked B, the stairs were supported at the entry and exit edge by a steel profile L $80 \times 60 \times 8 \mathrm{~mm}$ (Fig. 6b).

In accordance with the selected numerically analysed prefabricated staircase with one-sided suspended stairs, two prototypes of the staircase in versions A and $\mathrm{B}$ in the scale 1:1 were made in the testing laboratory of the Institute of Building Testing, Faculty of Civil Engineering, Brno University of Technology. The staircase prototypes consisted of 15 stairs of the length of $900 \mathrm{~mm}$, width of $314 \mathrm{~mm}$ and thickness of $40 \mathrm{~mm}$ and an atypical exit stair (Fig. 3). The height of both staircases was $3.0 \mathrm{~m}$, the handrail and the entry and exit newels were of a rectangular cross-section $50 \times$ $140 \mathrm{~mm}$. The position of the handrail was secured with the entry and exit newels. The handrail was connected to four stairs No. 4, 7, 10 and 13 with steel bars $\varnothing 12 / 2 \mathrm{~mm}$, which ran through a stainless steel newel and a height-rectifiable distance element $\varnothing 32 / 1.85 \mathrm{~mm}$ made of stainless steel. The steel profiles L $80 \times 60 \times$ $8 \mathrm{~mm}$ were fixed to the wall with fixings Fischer FUR $10 \times 115 \mathrm{~T}$ and screws $\varnothing 7 \mathrm{~mm}$.

The prototypes of staircases were experimentally tested in accordance with ETAG 008 - Guideline for European technical approval of prefabricated stair kits, edition January 2002. The results of tests were used for the verification of the precision and function of the designed modifications. The load tests monitored the response of the structures to the effect of a static load.

Within the experimental tests, the measured time data, i.e. the size of vertical displacement, were continu- ously recorded,. The loading scheme selected at the effect of the static load was chosen so as to model the effects of the uniform serviceability load $\left(V=3.0 \mathrm{kN} / \mathrm{m}^{2}\right)$ determined on the basis of Czech design standard ČSN EN 1991-1-1. The load was applied on the staircase with the use of loading boxes (Fig. 7). The boxes were placed on the staircase in such order, that the course of the bending moment drew as close to the course of the homogeneous distributed load, i.e. $2^{\text {nd }}$ degree parabola. The reverse action was applied for the unloading.

During the static loading tests, the values of vertical displacements at the stair faces at the selected 12 stairs (Fig. 5a) were continuously recorded with the MS04 with the accuracy of $0.05 \mathrm{~mm}$ and the measurement units HBM SPIDER 8 (2006). The measuring points were located in the middle of the width and thickness of the stairs. Two stairs No. 6 and 11 were also equipped with potentiometric trajectory sensors (Fig. 5a) in order to monitor vertical displacements at the bearing wall. The position of the measuring points was selected at the lower side of the stairs in the middle of the stairs $30 \mathrm{~mm}$ of the edge.

\subsection{Staircase A}

3.1. Stubište A

The staircase A was loaded in compliance with Czech design standard ČSN 732030 (1994) in two steps. In the first step, the staircase was loaded with uniform serviceability load $\left(V=3.0 \mathrm{kN} / \mathrm{m}^{2}\right)$, which was increased in the second step by the 0.3 multiple of the uniform serviceability load (Fig. 7). Under the effects of the increased load (1.3 multiple of uniform serviceability load), an extreme value of vertical displacement of $20.66 \mathrm{~mm}$ occurred at the stair No. 8, which is lower than the limit value according to (ETAG 008/2002, 2002; ČSN EN 1995-1-1, 2006) amounting to $29.797 \mathrm{~mm}\left((1 / 200) \times L_{S} / \cos \alpha ; L_{S}=4.862 \mathrm{~m}\right.$ (Fig. $5 b) ; \alpha=35.3281^{\circ}$ ) (Table 2). The course of vertical displacements measured under gradual loading allows to clearly identify the course of loading and the moments, when the glued contact of the top (or bottom) 


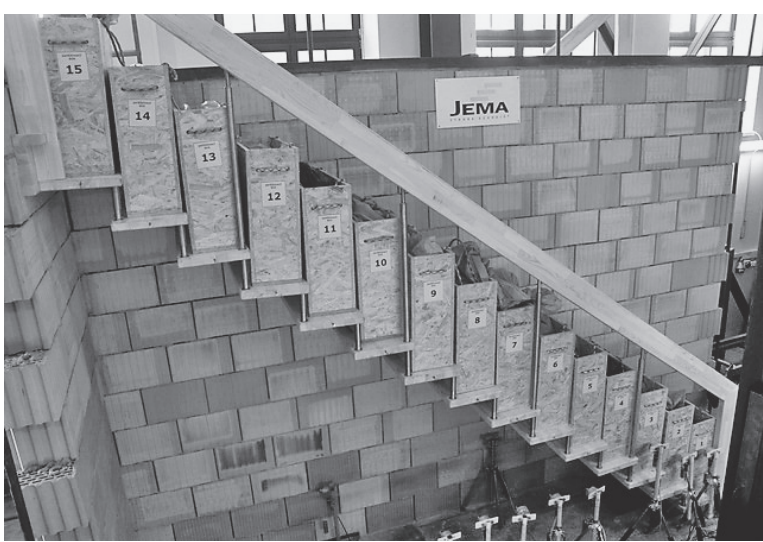

Figure 7 Prototypes of the staircase in version A during static load test - staircase loaded with uniform serviceability load $\left(V=3.0 \mathrm{kN} / \mathrm{m}^{2}\right)$ increased by the 0.3 multiple

Slika 7. Prototip stubišta verzije A tijekom testa statičkog opterećenja - stubište je opterećeno ravnomjernim opterećenjem $V=3,0 \mathrm{kN} / \mathrm{m}^{2}$ uvećanim za 0,3 puta

newel with the handrail was broken and opened. The values of vertical displacements in individual load steps are shown in Table 3. The graphical time record of vertical displacement of the static load test of the staircase A is shown in Fig. 8.
When relieving the load, there is a structure response and after the complete unloading, permanent irreversible deformations (notation PD in Table 3) appear amounting to 1.3 multiple of the uniform serviceability load of approx. $13.7 \%$. Under the loading, breaking occured as well as partial opening of the glued contact of the top (or bottom) newel with the handrail, while the screw contact showed no faults and the joint between the top and bottom newel and stairs was slightly opened and a distance element was partially displaced from the bottom washer. Some anchoring screws from the bearing wall were slightly pulled out at some stairs, which was manifested by the turning of the steel L $80 \times 60 \times 8$ profile. After the load relief of the staircase A, the partially opened glued contact of the bottom and top newel, respectively, with the handrail was closed up.

\subsection{Staircase B \\ 3.2. Stubište $B$}

The staircase B was loaded with the uniform serviceability load in three steps in compliance with standard ČSN 732030 (1994). In the first step, the staircase was loaded with uniform serviceability load $(V=3.0 \mathrm{kN} /$ $\mathrm{m}^{2}$ ), which was increased in the second step by the 0.3

Table 2 Maximum measured vertical displacement $U_{Y}(\mathrm{~mm})$ for staircase A and B for uniform serviceability load with self-weight compared with theoretical values (ETAG 008/2002, 2002; ČSN EN 1995-1-1, 2006)

Tablica 2. Maksimalno izmjereni vertikalni pomak $U_{Y}(\mathrm{~mm})$ za stubište A i B pri ravnomjernom opterećenju korisnika i opterećenju težinom stubišta u usporedbi s teorijskim vrijednostima (ETAG 008/2002, 2002; ČSN EN 1995-1-1, 2006.)

\begin{tabular}{|c|c|c|c|c|c|}
\hline \multicolumn{2}{|c|}{ Staircase A / Stubište A } & \multicolumn{3}{c|}{ Staircase B / Stubište B } \\
\hline$U_{\mathrm{Y}}$ & & $(1 / 200) \times L_{S} / \cos \alpha$ & $U_{\mathrm{Y}}$ & & $(1 / 200) \times L_{S} / \cos \alpha$ \\
\hline 20.540 & $<$ & 29.797 & 13.320 & $<$ & 29.797 \\
\hline Condition is satisfied. / Uvjet je zadovoljen. & \multicolumn{2}{|c|}{ Condition is satisfied. / Uvjet je zadovoljen. } \\
\hline
\end{tabular}

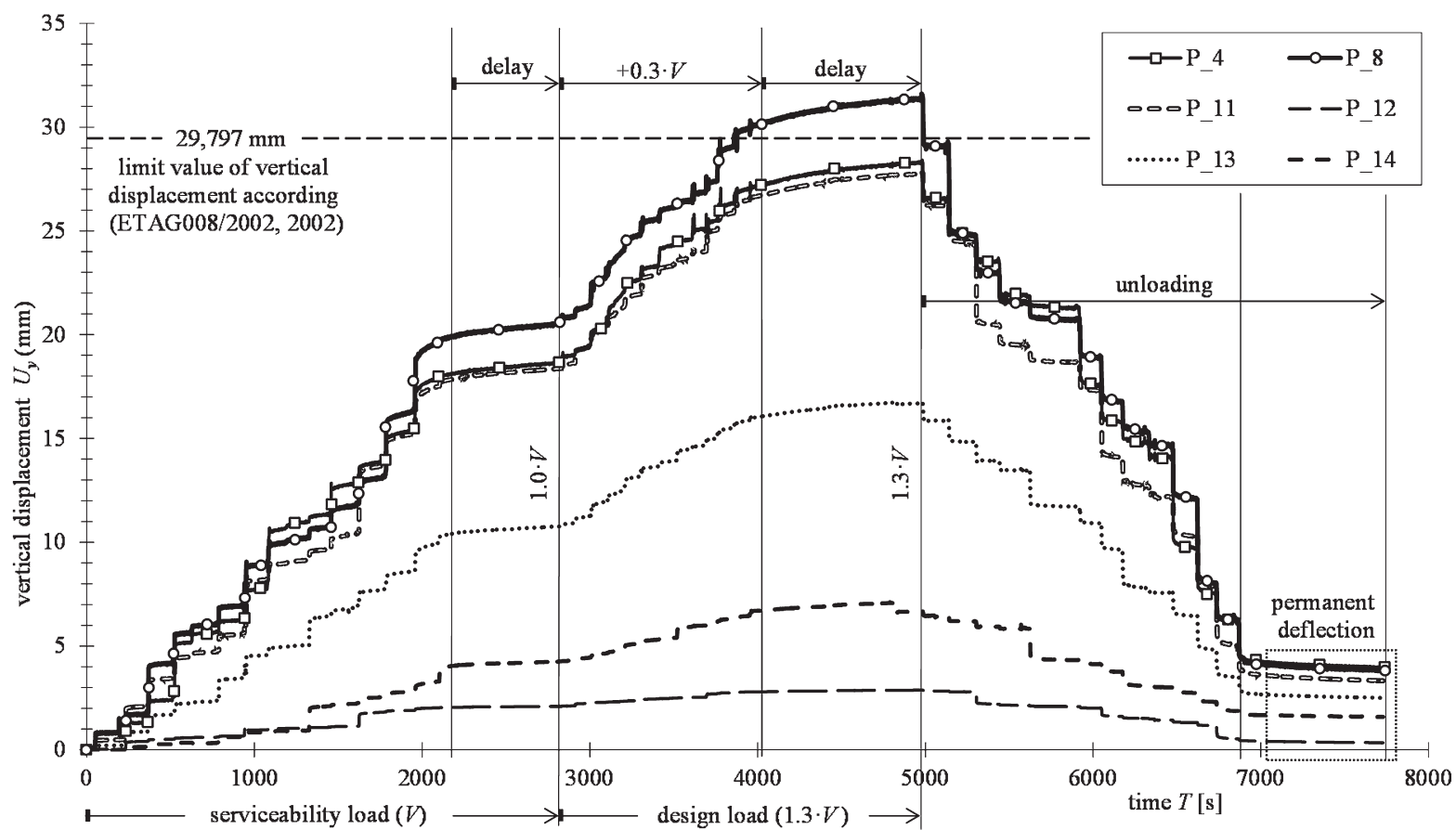

Figure 8 Time record of vertical displacement $U_{Y}(\mathrm{~mm})$ of the static load test of the staircase A; numbers of potentiometric sensors of the type MS04 according to Fig. 5

Slika 8. Vremenski zapis vertikalnog pomaka $U_{Y}(\mathrm{~mm})$ pri testu statičkog opterećenja stubišta A mjerenoga potenciometrijskim senzorima tipa MS04 sukladno slici 5. 
Table 3 Measured vertical displacements in individual load steps $U_{Y}(\mathrm{~mm})$ for staircase A and B

Tablica 3. Izmjereni vertikalni pomak $U_{Y}(\mathrm{~mm})$ za različita opterećenja stubišta A i B

\begin{tabular}{|c|c|c|c|c|c|c|c|c|c|}
\hline \multirow{3}{*}{ 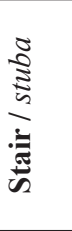 } & \multirow{3}{*}{ 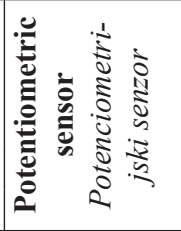 } & \multicolumn{4}{|c|}{$\begin{array}{c}\text { Staircase A / Stubište A } \\
\text { Vertical displacement } \boldsymbol{U}_{Y}(\mathbf{m m}) \\
\text { Vertikalni pomak, } U_{Y}(\mathrm{~mm})\end{array}$} & \multicolumn{4}{|c|}{$\begin{array}{c}\text { Staircase B / Stubište B } \\
\text { Vertical displacement } \boldsymbol{U}_{Y}(\mathbf{m m}) \\
\text { Vertikalni pomak, } U_{Y}(\mathrm{~mm})\end{array}$} \\
\hline & & $1.0 \cdot \mathrm{V}$ & $1.3 \cdot V$ & $\mathrm{PD}$ & $\%$ & $1.0 \cdot \mathrm{V}$ & $1.5 \cdot \mathrm{V}$ & PD & $\%$ \\
\hline & & & (a) & (b) & (a) $/(\mathrm{b})$ & & (c) & (d) & $(\mathrm{c}) /(\mathrm{d})$ \\
\hline 1 & P_1 & 3.890 & 7.030 & 1.580 & 22.5 & 3.090 & 4.480 & 0.490 & 10.9 \\
\hline 2 & P_2 & 9.790 & 15.640 & 3.600 & 23.0 & 7.270 & 13.030 & 1.290 & 9.9 \\
\hline 3 & P_3 & 12.100 & 19.070 & 3.660 & 19.2 & 7.610 & 15.760 & 1.810 & 11.5 \\
\hline 5 & P_4 & 18.900 & 28.243 & 3.970 & 14.1 & 12.210 & 25.240 & 3.180 & 12.6 \\
\hline 6 & P_5 & 19.530 & 29.500 & 3.740 & 12.7 & 12.600 & 26.380 & 3.310 & 12.5 \\
\hline 6 & P_6 (wall) & 1.890 & 2.420 & 0.160 & 6.6 & 1.070 & 1.891 & 0.190 & 10.0 \\
\hline 7 & P_7 & 19.760 & 30.270 & 3.870 & 12.8 & 12.950 & 27.480 & 3.290 & 12.0 \\
\hline 8 & P_8 & 20.660 & 31.050 & 3.870 & 12.5 & 13.480 & 28.750 & 3.480 & 12.1 \\
\hline 9 & P_9 & 19.177 & 28.954 & 3.593 & 12.4 & 12.772 & 27.457 & 3.697 & 13.5 \\
\hline 10 & P_10 & 18.705 & 28.107 & 3.491 & 12.4 & 12.644 & 26.594 & 3.844 & 14.5 \\
\hline 11 & P_11 & 18.546 & 27.680 & 3.324 & 12.0 & 12.461 & 25.724 & 4.047 & 15.7 \\
\hline 11 & P_12 (wall) & 2.103 & 2.826 & 0.336 & 11.7 & 1.047 & 1.693 & 0.176 & 10.4 \\
\hline 13 & $P \_13$ & 10.862 & 16.653 & 2.500 & 15.0 & 7.567 & 16.051 & 2.993 & 18.6 \\
\hline 15 & P_14 & 4.277 & 6.951 & 1.584 & 22.8 & 2.940 & 6.595 & 1.624 & 24.6 \\
\hline
\end{tabular}

PD ... permanent deflection / trajni progib

multiple and in the third step by 0.2 multiple of the uniform serviceability load. Under the effects of the increased load (1.5 multiple of uniform serviceability load), an extreme value of vertical displacement of 13.48 mm occurred at the stair No. 8, which is lower than the limit value according to (ETAG 008/2002, 2002; ČSN EN 1995-1-1, 2006) amounting to $29.797 \mathrm{~mm}$ (Table 2). The second part of the graph (Fig. 9) shows a noticeably sharp rise of vertical displacements caused by the broken contact of the bottom newel with the handrail. The values of vertical displacements in individual load steps are shown in Table 3.

When relieving the load, there is again a noticeable structure response and after the complete load relief, permanent deformations (PD in Table 3) appear amounting to 1.5 multiple of the uniform serviceability load of approx. $12.8 \%$. Similarly to the situation with staircase A, breaking and partial opening of the glued contact of the top newel with the handrail occurred under this load. In addition, a partial split of the handrail

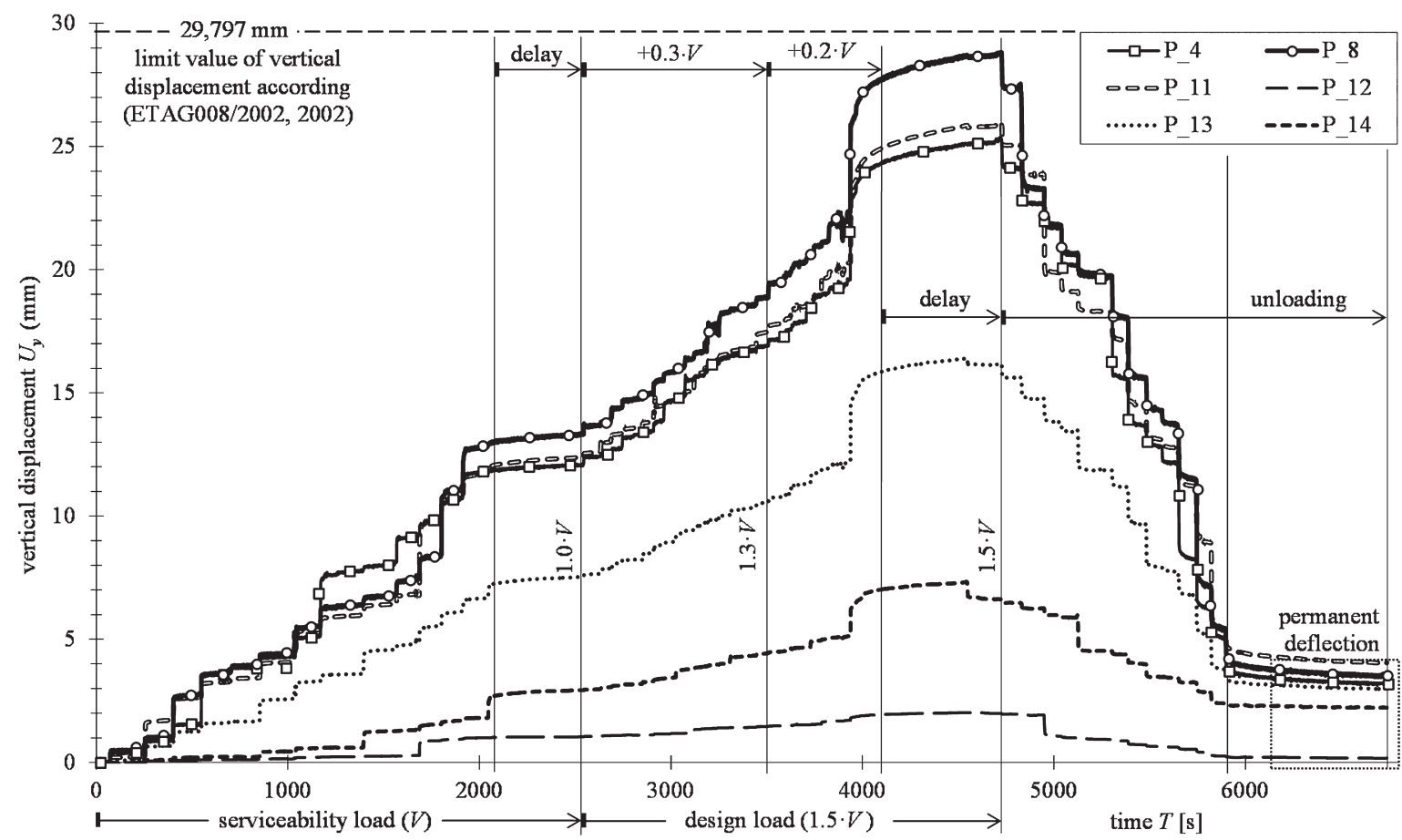

Figure 9 Time record of vertical displacement $U_{Y}(\mathrm{~mm})$ of the static load test of the staircase B; numbers of potentiometric sensors of the type MS04 according to Fig. 5

Slika 9. Vremenski zapis vertikalnog pomaka $U_{Y}(\mathrm{~mm})$ pri testu statičkog opterećenja stubišta B mjerenoga potenciometrijskim senzorima tipa MS04 sukladno slici 5. 
appeared. The distance of the handrail and the newel reached approx. $3 \mathrm{~mm}$. Some anchoring screws from the bearing wall were slightly pulled out at some stairs, which was manifested by the turning of the steel L 80 $\times 60 \times 8$ profile. After the load relief of the staircase A, the opened glued contact of the bottom newel with the handrail was not closed up.

\subsection{Evaluation of static loading tests of staircase $A$ and $B$}

3.3. Ocjena testova statičkog opterećenja stubišta A i B

The evaluation of static loading tests of prefabricated staircases with one-sided suspended stairs in versions $\mathrm{A}$ and $\mathrm{B}$ was performed according to (ETAG 008/2002, 2002; ČSN EN 1995-1-1, 2006). This condition was met by both staircases. Staircase A was loaded by 1.3 multiple of the uniform serviceability load. After applying the same load, the staircase B continued to be loaded up to 1.5 multiple of the uniform serviceability load. The values of the ratio between the permanent and total deformation for staircases $\mathrm{A}$ and $\mathrm{B}$ are lower than the coefficient $\lambda_{1}$, which, according to Section D. 8 (ČSN 732030,1994 ), amounts to 0.25 and $25 \%$, respectively, for glued structures. Both staircases met these criteria of reliability in terms of ultimate limit state.

The comparison of experimentally measured values of vertical displacements for comparable load shown in Table 3 for 1.0 multiple and 1.3 multiple of uniform serviceability load shows that staircase B is stiffer than staircase A.

\section{CONCLUSION}

4. ZAKLJUČAK

The comparison of the measured data showed that the prototype of staircase B is stiffer and more resistant to the applied load than the prototype of staircase A. Regarding statics, this finding indicates that supporting stairs with two steel profiles L $80 \times 60 \times 8 \mathrm{~mm}$ is more advantageous than the combination of a steel profile and a rectifiable stainless steel distance element.

During a static loading test, staircases A and B were loaded by their own weight and then by uniform serviceability load of the intensity of $V=3.0 \mathrm{kN} / \mathrm{m}^{2}$. Subsequently, the load of staircases A and B was increased up to 1.3 multiple for staircase $A$ and up to 1.5 multiple of the load for staircase B. Even under the higher load, the vertical displacements of selected measuring points at staircase B were lower than those at staircase A. Under the effects of increased loading, which models the ultimate limit state, the staircase structure showed no serious faults and deficiencies. It should be emphasised that the pressing of newel washers into stairs occurred as well as opening of the contact between the bottom newel and handrail for staircases A and B, and opening of the contact between the top newel and handrail for staircase B. Despite these slight faults, the structures of staircases were reliable, which was documented by subsequently performed loading tests of broken and opened contacts.
Staircases A and B were evaluated in accordance with (ETAG 008/2002, 2002; ČSN EN 1995-1-1, 2006; ČSN 73 2030, 1994) in terms of ultimate and serviceability limit state. Both staircases A and B met the required criteria of the mentioned regulations.

Based on the behaviour of staircases in the course of loading tests, it was recommended to increase ultimate limit state of staircases structure and their general stiffness by changes in the detail of the contact of the top and bottom newel with handrail, and the detail of the passage of the exit stair through the top newel.

\section{Acknowledgements - Zahvala}

The experimental testing of prefabricated staircases with one-sided suspended stairs has been financially supported by the project of MPO ČR IMPULS, registration number FI-IM2/053. The article is supported by a research project FAST-S-15-2757 from the Internal Grant Agency, Brno University of Brno, Brno and by the European Social Fund and the state budget of the Czech Republic, project "The Establishment of an International Research Team for the Development of New Wood-based Materials" reg. no. CZ.1.07/2.3.00/20.0269. The authors also acknowledge the contribution of participating laboratories.

\section{REFERENCES}

\section{LITERATURA}

1. Berthelot, J. M., 1998: Composite Materials, Mechanical Behavior and Structural Analysis. Berlin: Springer.

2. Bucur, V., 2006: Acoustics of Wood. Berlin: Springer.

3. Danielsson, H.; Gustafsson, P. J., 2013: A three dimensional plasticity model for perpendicular to grain cohesive fracture in wood. Engineering Fracture mechanics, 98: 137-152.

http://dx.doi.org/10.1016/j.engfracmech.2012.12.008

4. Fleischmann, M.; Müllner, H. W.; Krenn, H., Eberhardsteiner, J., 2005: Experimental and Numerical Investigation of Timber Structures for the Validation of an Orthotropic Plasticity Model. 22nd Danubia-Adria Symposium on Experimental Methods in Solid Mechanics (DAS-22), Monticelli Terme - Parma, Italy.

5. Franke, B.; Quenneville, P. J., 2011: Numerical Modelling of the Failure Behavior of Dowel Connections in Wood. Journal of Engineering Mechanics. 137(3): 186195.

http://dx.doi.org/10.1061/(ASCE)EM.19437889.0000217

6. Galicky, J.; Czech, M., 2013: A new approach to formulate the general strength theories for anisotropic discontinuous materials. Part A: The experimental base for a new approach to formulate the general strength theories for anisotropic materials on basis of wood. Applied Mathematical Modelling, 37(3): 815-827. http://dx.doi.org/10.1016/j.apm.2012.03.004

7. Habermann, K. J., 2002: Staircases: Design and Construction. Basel, Boston, Berlin: Birkhäuser.

8. Hoffman, O., 1967: The Brittle Strength of Orthotropic Materials. Journal of Composite Materials, 1: 200-206. http://dx.doi.org/10.1177/002199836700100210

9. Jiricna, E., 2001: Staircases. New York, NY: WatsonGuptill Publications. 
10. Karre, A., 2005: Stairscaping: A Guide to Buying, Remodeling, and Decorating Interior and Exterior Staircases. Massachusetts: Quarry Books.

11. Kretschmann, D. E., 2010: Wood Handbook, Chapter 05: Mechanical Properties of Wood. General Technical Report FPL-GTR-190. Madison, WI: U.S. Department of Agriculture, Forest Service, Forest Products Laboratory: 5-1 - 5-46.

12. Labans, E.; Kalniņš, K., 2012: Numerical Modelling and Experimental Validation of Dendrolight Cellular Wood Material. In: The 8th Meeting "Northern European Network for Wood Science and Engineering (WSE)": Proceedings: The 8th Meeting of the Northern European Network for Wood Science and Engineering (WSE), Lithuania, Kaunas, 13-14 September, 2012. Kaunas: 2012, pp.177-184. (online: http://www.nordicforestresearch.org/wp-content/uploads/2011/03/26 Edgars_Labans.pdf)

13. Matovič, A., 1993: Fyzikální a mechanické vlastnosti dřeva a materiálů na bázi dřeva, Brno: Vysoká škola zemědělská.

14. Mascia, N. T.; Lahr, F. A. R., 2006: Remarks on orthotropic elastic models applied to wood. Materials Research, 9 (3): 301-310. http://dx.doi.org/10.1590/S1516-14392006000300010

15. Pěnčík, J.; Lavický, M., 2006: Možnosti modelování lepených dřevěných spojů pomocí prvků CONTA17x. (Modeling capabilities of glued wood joints with contact elements CONTA17x) 14. ANSYS Users Meeting pro Českou republiku a Slovensko 2006, Tábor. Tábor: SVS FEM s.r.o., pp. 1-9.

16. Pousette, A., 2003: Full-scale test and fi nite element analysis of a wooden spiral staircase. Holz als Roh-und Werkstoff, 61(1): 1-7. http://dx.doi.org/10.1007/s00107-002-0345-6

17. Pousette, A., 2006: Testing and modeling of the behavior of wooden stairs and stair joints. J Wood Sci, 52: 358362. http://dx.doi.org/10.1007/s10086-005-0778-8

18. Požgaj, A.; Chovanec, D.; Kurjatko, S.; Babiak, M., 1997: Štruktura a vlastnosti dreva, Priroda, Bratislava.

19. Tankut, N.; Tankut, A. N.; Zor, M., 2014: Finite Element Analysis of Wood Materials. Drvna industrija, 65 (2): 159-171. http://dx.doi.org/10.5552/drind.2014.1254

20. ***2004: "Fyzikální a mechanické vlastnosti dřeva" (online), Mendel University in Brno, wood.mendelu.cz/cz/ sections/Props/?q=node/56. First published 2004 (Accessed Aug. 1, 2013).
21. ***2006: "Spider8 from HBM" (online), HBM Inc. http://www.hbm.com/fileadmin/mediapool/hbmdoc/ technical/b0409.pdf. First published 2006 (Accessed May 20, 2013).

22. ***2012: "Elastic Properties and Young Modulus for some Materials" (online), The Engineering Toolbox, www.engineeringtoolbox.com/young-modulus-d_417. html. First published 2012 (Accessed May 15, 2013).

23. *** ANSYS ${ }^{\circledR}$ Academic Research, Release 14.5, ANSYS, Inc., 2012a.

24. *** ANSYS ${ }^{*}$ Academic Research, Release 14.5, Help System, Elements Reference, ANSYS, Inc., 2012b.

25. *** ANSYS ${ }^{*}$ Academic Research, Release 14.0, Help System, Advanced Analysis Techniques Guide, ANSYS, Inc., 2012c.

26. *** ČSN 49 1531-1, 1998: Structural timber - Part 1: Visual strength grading.

27. *** ČSN 73 2030, 1994: Loading tests of building structures Common regulations.

28. *** ČSN 73 4130, 2010: Stairways and sliding ramps Basic requirements.

29. *** ČSN EN 1990 (73 0002) Eurocode, 2004: Basis of structural design.

30. *** ČSN EN 1991-1-1 (73 0035) Eurocode 1, 2004: Action on Structures - Part 1-1: General actions - Densities, self-weight, imposed loads for buildings.

31. *** ČSN EN 1995-1-1 (73 1701), 2006: Design of timber structures, Part 1-1: General - Common rules and rules for buildings.

32. *** ETAG 008/2002, 2002: Guideline for European technical approval of prefabricated stair kits. Prefabricated stair kits in general.

33. *** IDA NEXIS 32, 2002: SCIA Group.

34. *** JEMA Svitavy a.s., 2006: Wooden staircase. Product catalog.

\section{Corresponding address:}

Assist. Prof. Ing. JAN PĚNČÍK, Ph.D.

Institute of Building Structures

Faculty of Civil Engineering

Brno University of Technology

CZECH REPUBLIC

e-mail: pencik.j@fce.vutbr.cz 